\title{
FROM MINDFUL EATING TO MINDFULNESS IN COPD
}

\author{
Anca Hâncu' ${ }^{1}$, Florin Mihălţan² \\ ${ }^{1}$ Lotus-Med Clinic Bucharest, Romania \\ University of Medicine and Pharmacy "Carol Davila" Bucharest, Romania \\ Corresponding author: Anca Hâncu, ancahancu@gmail.com
}

\begin{abstract}
Mindfulness is a complex mental state meaning paying attention to the present moment but non judgemental, practically awareness of present. Developed like a form of mental training, has the objective to replace automatic or reactive modes of mind.

Processes to improve a non-judgemental attitude by mindfulness meditation and cognitive training may relieve psychological distress in COPD, where stigma and self blame, associated with depression are highly prevalent. Mindfulness based trainings could be included as add on treatments in pulmonary rehabilitation programs, with a hope to improve patients self-care and adherence.
\end{abstract}

Keywords: COPD, pulmonary rehabilitation programs, mindfulness, psychological distress, depression.

\section{Rezumat}

Mindfulness este o stare mentală complexă caracterizată prin concentrarea atenției asupra momentului prezent, dar fără a judeca, practic o conștientizare a prezentului. Dezvoltată ca o formă de antrenament al minții, are ca obiectiv înlocuirea modurilor de gândire automate sau reactive.

Procesul de îmbunătățire a atitudinii lipsite de judecată critică prin meditația de tip mindfulness și prin formarea cognitivă pot ameliora problemele psihologice ale pacienților cu BPOC, în rândul cărora stigmatizarea și sentimentul de vinovăție, asociate cu depresia sunt foarte răspândite. Tehnicile de formare a minții de tip mindfulness ar putea fi incluse ca tratament suplimentar în programele de reabilitare pulmonară, în speranța de a îmbunătăți îngrijirea și aderența la tratament a pacienților.

Cuvinte cheie: BPOC, programe de reabilitare pulmonară, mindfulness, distres psihologic, depresie. 


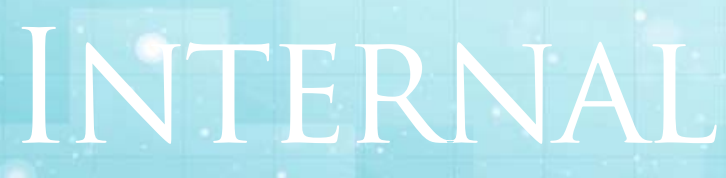

General Reviews

Mindfulness is a complex mental state meaning paying attention to the present moment but non judgemental, practically awareness of present. Developed like a form of mental training, has the objective to replace automatic or reactive modes of mind $^{(1)}$. Initially practiced as meditation, mindfulness mediates effects on mood and behaviour.

Mindfulness, today broadly conceptualized is a non-judgemental, nonelaborative, present centred awareness for which sensations, feelings and thoughts arising are acknowledged and accepted as they are.

Without automatic reaction, like the known model of reactivity, feelings and thoughts are just observed; this state of " observation " can introduce a " space " between perception and response for each patient and enable reflexive answer. This reflexivity will help disease and symptoms perceptions and will be a support for patients in self management and therapy adherence.

There are 2 key components of mindfulness, firstly self regulation of attention on immediate experience, acknowledging present mental events, but maintaining prolonged periods of sustained attention is necessary. As focal point is described the breath, as meditation practice, shifting awareness.

Attention switching allows the patient to bring attention back to the breath when a feeling, sensation, thought is acknowledged. Experiencing events and thoughts are not anymore considered distraction, but objects of observation. Attention will be switched back to breath, once acknowledged, preventing further elaboration.

Second key component: the orientation to experience with acceptance, openness and curiosity ${ }^{(1)}$ Then, the conscious decision will be to be open to the reality, living the present moment. One example of the observation process is to notice how a feeling could evoke a judgemental thought and then heighten the unpleasantness of the feeling. The central point is the transient nature, impermanence of feelings and thoughts. Finally, people should recognise thoughts simply as thoughts that are not real. Summarizing, mindfulness means focus on altering the impact and response to thoughts , sensations and feelings.

indfulness was successfully applied to mindful eating, interrupting automatic response to external food cues and prevent emotional triggers that generate responses and excessive food consumption (2). Automatic eating, by definition means impulsive, emotional and habitual eating ${ }^{(3)}$. Mindfulness, by training and practice will allow a deliberate process to be developed instead quick reactions or impulsive actions. MB-EAT Mindfulness based eating awareness training is designed as an intervention 
promoting mindful eating ${ }^{(4)}$. Helping people with obesity or overweight to recover their normal weight. Initially was developed for people with binge eating disorders, meaning eating a large quantity of food in a limited period of time.

Raisin meditation means eating a single raisin mindfully, as if for the first time. The cycle of automatic eating can be broken by eating a raisin without a distraction, emotional interference or impulse.

Raisin meditation and different guided meditations are examples used to manage weight and eating related self regulation. These types of interventions addresses hunger and satiety as primary mechanisms. Finally, mindful awareness will lead to "mindful" choices in front of a buffet. MB-EAT will combine inner wisdom, awareness of inner experiences with outer wisdom, using nutrition knowledge to help including data about energy and nutrient content in everyday choices ${ }^{(15)}$.

Important learning is sensory specific satiety, when after a relatively small amount of food, taste receptors decrease their sensitivity to taste ${ }^{(5)}$ and people will learn to stop eating earlier. Awareness of the moment when pleasure from specific food decreases helps patients maximize pleasure only with small portions.

MB-EAT will help eating as a response to hunger and satiety, not emotionally, to interrupt automatic eating and cultivate awareness of internal / external triggers.

About mindfulness, it is not enough to "let it go“(6). We cannot decide immediately to live in the present and instantly to change learnings and routines achieved in many years. But is interesting how mindfulness can change eating behaviors, but also improving symptoms perception and change the way of living, for people with COPD and obesity, acting from 2 ways, targeting obesity, but also targeting pulmonary symptoms. Greater attention and awareness can help people respond reflexively instead of maintaining habitual patterns.

Evidence indicates that MBSR ( mindfulnessbased stress reduction) and MBCT (mindfulness based cognitive therapies) are associated with improvements in depressive symptoms, anxiety, stress, quality of life and selected physical outcomes in the adjunct treatment of cancer, cardiovascular disease, chronic pain, chronic somatic disease, depression, anxiety disorders, other mental disorders and in prevention in healthy adults and children ${ }^{(7)}$.

\section{How mindfulness could improve syntomps in COPD patients? Which are scientific proofs related to this subject?}

Processes to improve a non-judgemental attitude by mindfulness meditation and cognitive training may relieve psychological distress in COPD, where stigma and self blame, associated with depression are highly prevalent.

Mindfulness cognitive based therapy (MBCT) is an intervention that adds parts of cognitive behavioral therapy to mindfulness meditation. MBCT will facilitate psychological distress by increased levels of self compassion $^{(1)}$. MBCT support the patient in recognizing wrong sensations, cognitions in a non-judgmental way. When thoughts can be controlled in a compassionate manner, MBCT will be a good approach to understand and reduce self blaming, different dezastrous cognitions and even exaggeration of body sensations, for example breathless. All of these have been related to depression, demobilization and high anxiety ${ }^{(8)}$.

Mainly undertreated in COPD, physiological 


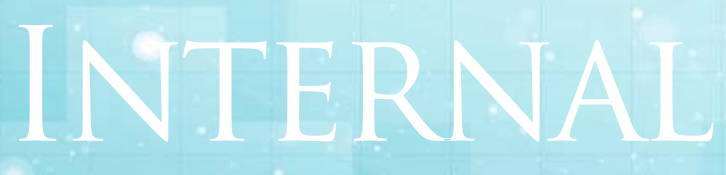

General Reviews

distress is associated with physical status impairment, inflammation, low physical activity $^{(9,10)}$. Additional medication will bring additional difficulties for patients already on long term therapies ${ }^{(11,12)}$. for that reason treating depression with add on therapies should be difficult.

A high percentage of patients with COPD in pulmonary rehabilitation programs are reporting high levels of depression (27\%) and anxiety $(32 \%)^{(1)}$. Another new metaanalysis ${ }^{(13)}$ reveals that meditative techniques and relaxation are improving psychological and physical outcomes in COPD. For the first time, Farver - Vestergard in their cluster randomized controlled trial , published in Eur Respir J in 2018, intended to evaluate the efficacy of MBCT as additional intervention for pulmonary rehabilitation ${ }^{(14)}$. The assessment was psychological distress and impairment of physical health status in COPD as primary outcome. Secondary objectives are triggering inflammatory cytokines, which are induced by psychological distress and play an important role in COPD. Their level could be reduced by $\mathrm{MBI}^{(16)}$. Their assumption was based on previous results of MBCT in psychological and physical outcomes in other chronic diseases. The study was conducted in Denmark, with 2 arms, one PR + MBCT and the other, the control was receiving only $P R$ (pulmonary rehabilitation). Patients included after spirometry diagnosis confirmed FEV1 $<50 \%$, dyspnea score $>3$ and physical capability to attend the exercise component of PR.

Primary outcome measures - assessed psychological distress using HADS ${ }^{(17)}$. Hospital Anxiety and Depression Scale. Assessing physical health status impairment was done by CAT - the COPD Assessment Test. For secondary outcome measurement, daily physical activity was measured and blood tests for cytokines.

From the COPD - MBCT program, we can underline some exercises. Awareness of "automatic pilot", automatic activity, exercise for connecting with emotions, noticing negative thoughts, understand difficult situations and learn to "let them go". Important point is to understand that "thoughts are not facts" practically to understand emotional reactions, to make the difference between anxiety, emotions, bad mood and reality. An important exercise, especially for elderly people is "how can I best take care of myself?" All these exercises will help patients to perceive disease and symptoms in a better way and to be more adherent to therapies and to a healthy lifestyle.

The secondary outcome, cytokine levels measurement, revealed TNF $\alpha$ significant increase after treatment only in the arm with $\mathrm{PR}$ alone. That means MBCT prevented the 
exacerbation of TNF $\alpha$ mediated inflammation, this cytokine is playing a role in lung diseases, then TNF $\alpha$ may be a significant target in inflammatory diseases ${ }^{(18)}$.

Increased levels of self compassion, may facilitate the effect of MBCT on psychological distress. Authors concluded that the study revealed that encouraging a non-judgemental attitude by mindfulness meditation may relieve psychological distress in COPD, a disease with highly prevalent anxiety and depression.

In conclusion, mindfulness based trainings could be included as add on treatments in pulmonary rehabilitation programs, with a hope to improve patients self-care and adherence.

\section{Bibliography}

1. BishopSR, Lau M, Shapiro S et al, Mindfulness: a proposed operational definition. Clin Psychol Sci Pract 2004; 11: 230-241

2. Forman EM, Shaw JA, Goldstein SP et al. "Mindful decision making and inhibitory control training as complementary means to decrease snack consumption. Appetite 2016; 103; 176-183

3. Mantzios M, Wilson JC, Mindfulness, eating behaviors and obesity: a review and reflection on current findings, Current Obes Rep 2015; 4: 141-146

4. Kristeller $J L$, Wolever $R Q$, Mindfulness based eating awareness training for treating binge eating disorder : the conceptual foundation Eat Dis 2011; 19:49-61

5. Jones PW, Harding G, Berry $P$, et al. Development and first validation of the COPD Assessment Test. Eur Respir J 2009; 34: 648-654.

6.Cazzola M, MacNee W, Martinez FJ, et al. Outcomes for COPD pharmacological trials: from lung function to biomarkers. Eur RespirJ 2008; 31: 416-468.
7. Gotink RA, Chu P, Busschbach JJV, Benson H, Fricchione GL, Hunink MGM 2015 Standardised mindfulness based interventions in healthcare: An overview of systematic reviews and meta-analyses of RCTS. PLOS ONE 10 (4): e0124344

8. Moore MC, Zebb BJ. The catastrophic misinterpretation of physiological distress. Behav Res Ther 1999; 37:1105-1118.

9. Pumar MI, Gray CR, Walsh JR, et al. Anxiety and depression: important psychological comorbidities of COPD. J Thorac Dis 2014; 6: 1615-1631.

10. Yohannes AM, Alexopoulos GS. Depression and anxiety in patients with COPD. Eur Respir Rev 2014; 23:345-349.

11. Fritzsche $A$, Clamor $A$, von Leupoldt $A$. Effects of medical and psychological treatment of depression in patients with COPD: a review. Respir Med 2011; 105: 1422-1433.

12. Yohannes AM, Alexopoulos GS. Pharmacological treatment of depression in older patients with chronic obstructive pulmonary disease: impact on the course of the disease and health outcomes. Drugs Aging 2014; 31:483-492.

13. Volpato $E$, Banfi $P$, Rogers SM, et al. Relaxation techniques for people with chronic obstructive pulmonary disease : a systematic review and a meta-analysis. EvidBased Complementary Altern Med 2015: 1-22.

14. Farver-Vestergaard I, O'Toole MS, O'Connor M, et al. Mindfulness-based cognitive therapy in COPD: a cluster randomised controlled trial. Eur Respir J 2018; 51: 1702082

15. Carla K Miller, "Mindful eating with diabetes", From research to practice, vol 30, $n r$ 2, spring 2017

16. Rosenkranz MA, Davidson RJ, Maccoon DG, et al. A comparison of mindfulness-based stress reduction and an active control in modulation of neurogenic inflammation. Brain Behav Immun 2013; 27: 174-184.

17. Zigmond AS, Snaith RP. The Hospital Anxiety and Depression Scale. Acta Psychiatr Scand 1983; 67: 361-370. 18. Matera MG, Calzetta L, Cazzola M. TNF-alpha inhibitors in asthma and COPD: we must not throw the baby out with the bath water. Pulm Pharmacol Ther 2010; 23: 121-128. 